\title{
Peran Gereja dalam Penegakan Hak Asasi Manusia di tengah Keberagamaan
}

\author{
Vony Sulistyorini ${ }^{1}$, Riko Silaen ${ }^{2}$, Andries Yosua ${ }^{3}$ \\ Sekolah Tinggi Teologi Ekumene Jakarta \\ vonysulistyorini@sttekumene.ac.id
}

\begin{abstract}
Violations of human rights in the religion of these days are increasingly rampant, where most violations cannot be categorized by mild violations, but some have entered anarchist actions. This violated Article 22 of Law Number 39 of 1999 concerning Human Rights. So that if the violation is tolerated or allowed to continue to occur, the image of the country which is a sovereign entity for the orderly of the social society based on the law is not well-reflected. So in this journal, the authors reveal from personal perspectives and based on experience in living in the midst of a compound society how human rights violations in religion often occur. And hope that all efforts can be done optimally so that Indonesia will again become a fair, sovereign, and back to the spirit of unity. And the church must provide examples of exemptions to protect and respect human rights because the church believes human rights are derived from God (Gen. 1: 26-27).
\end{abstract}

Keywords: church; diversity; human rights; Indonesia

Abstrak: Pelanggaran Hak Asasi Manusia dalam keberagamaan hari-hari ini semakin marak terjadi, dimana pelanggaran tersebut kebanyakan tidak bisa dikategorikan pelanggaran ringan, tetapi beberapa sudah masuk tindakan anarkis. hal itu melanggar Pasal 22 Undang-Undang Nomor 39 Tahun 1999 tentang Hak Asasi Manusia. Sehingga jika pelanggaran tersebut ditolerir atau dibiarkan terus terjadi maka citra negara yang merupakan entitas yang berdaulat atas tertib sosial masyarakat berdasarkan hukum tidak tercermin dengan baik. Maka dalam jurnal ini penulis mengungkap dari perspektif pribadi dan berdasarkan pengalaman dalam hidup ditengah masyarakat yang majemuk bagaimana pelanggaranpelanggaran HAM dalam keberagamaan kerap terjadi. Dan berharap agar segala upaya bisa dilakukan dengan maksimal agar Indonesia kembali menjadi negara yang adil, berdaulat dan kembali memiliki semangat persatuan. Serta gereja harus memberikan contoh teladan bagimana melindungi dan menghormati HAM karena gereja percaya HAM adalah berasal daripada Tuhan (Kej 1: 26-27).

Kata Kunci: gereja; hak asasi manusia; keberagamaan; Indonesia

\section{Pendahuluan}

Hak Asasi Manusia (HAM) diadakan bukan karena pemberian oleh negara atau masyarakat tetapi karena manusia adalah makhluk hidup yang bermartabat. Tuhan menciptakan manusia untuk menguasai dan mengelola dunia ini dengan kemampuan berfikir, beradaptasi, bertumbuh dan berperasaan. Hal tersebut yang menjadikan manusia mempunyai martabat yang paling tinggi diantara semua makhluk hidup ciptaan Tuhan. Maka dari itu pengakuan atau eksistensi manusia patut diapresiasikan secara benar dan terhormat. Sejatinya HAM harus kita junjung tinggi, hormati, dan lindungi demi kehormatan dan martabat manusia. Para pendiri bangsa (founding father) yang telah membangun bangsa Indonesia dengan berlandaskan hukum dan menjamin rakyatnya dengan hak asasi manusia yang tertuang dalam 
UUD Negara Republik Indonesia tahun 1945. Didalam UUD NRI 1945 mengakui dan menghormati hak asasi seluruh manusia yang berada didalam wilayah negara Indonesia, penduduk yang berstatus resmi atau bukan diperlakukan sama sebagai manusia yang memiliki hak asasi yang diakui secara global.

Salah satu hak asasi manusia yang dijamin oleh negara dan tertuang dalam UUD NRI 1945 adalah hak kebebasan beragama, pasal 29 (2) "Negara menjamin kemerdekaan tiap-tiap penduduk untuk memeluk agamanya masing-masing dan untuk beribadat menurut agamanya dan kepercayaannya itu". ${ }^{1}$ Penjelasan lebih detail mengenai HAM juga tertulis dalam UndangUndang Republik Indonesia Nomor 39 Tahun 1999 tentang Hak Asasi Manusia dengan asasasas dasar (pasal 2) "Negara Republik Indonesia mengakui dan menjunjung tinggi hak asasi manusia dan kebebasan dasar manusia sebagai hak yang secara kodrati melekat pada dan tidak terpisahkan dari manusia, yang harus dilindungi, dihormati, dan ditegakkan demi peningkatan martabat kemanusiaan, kesejahteraan, kebahagiaan, dan kecerdasan serta keadilan". ${ }^{2}$

Maraknya permasalahan HAM telah menjadi isu global yang sangat penting, di Indonesia khususnya, menurut survei dalam masa pemerintahan Bapak Presiden Joko Widodo tahun 2014-2019 telah terjadi 846 peristiwa pelanggaran kebebasan beragama/berkeyakinan dengan 1.060 tindakan. Artinya, setiap bulan terjadi 14 peristiwa dengan 18 tindakan pelanggaran kebebasan beragama/berkeyakinan dalam lima tahun terakhir. ${ }^{3}$ Serta pada tahun 2020 Setara Institute juga melaporkan telah menemukan 180 pelanggaran kebebasan beragama/berkeyakinan (KBB), seluruh pelanggaran itu tertuang dalam 422 tindakan. $^{4}$

Berdasarkan latarbelakang di atas, maka penulis ingin mengangkat isu tentang kebebasan beragama yang adalah hak asasi manusia dengan rumusan masalah yaitu mengapa bisa terjadi kasus pelanggaran dalam kebebasan beragama? dan apa yang harus dilakukan demi terciptanya kebebasan beragama yang sesuai dengan hak asasi manusia. Tujuan penulisan adalah mengetahui penyebab terjadinya kasus pelanggaran kebebasan beragama dan solusinya agar hak asasi manusia dapat terpenuhi secara patut.

\section{Metode Penelitian}

Dalam jurnal ini metode penelitian yang digunakan adalah metode penelitian deskritif berdasarkan bahan-bahan dari kepustakaan dan data sekunder lainnya. Untuk menganalisisnya menggunakan pendekatan kualitatif yang mengacu pada norma hukum dalam perundangundangan yang berlaku sampai saat ini. menurut Sugiono (2005) pendekatan kualitatif adalah penelitian yang digunakan untuk meneliti pada kondisi objek alamiah. Dimana peneliti merupakan instrumen kunci $^{5}$. Akhir penulisan akan terdapat kesimpulan (deduktif) yang diambil dari sesuatu yang sifatnya umum dan sudah terbukti.

\section{Hasil dan Pembahasan}

Secara etimologi Agama berasal dari bahasa sansekerta, terdiri dari kata "A" yang berarti tidak dan kata "Gama" yang berarti kacau, jika disusun dapat diartikan sebuah keyakinan yang menghindarkan manusia atau orang percaya dari kekacauan sekaligus membentuk pola manu-

\footnotetext{
${ }^{1}$ Dewan Perwakilan Rakyat, “Undang Undang Dasar 1945," DPR.Go.Id.

${ }^{2}$ Republik Indonesia, "Undang-Undang No . 39 Tahun 1999 Tentang : Hak Asasi Manusia," Pusat Penerbitan, PNRI, no. 39 (1999): 43.

${ }^{3}$ Fathiyah Wardah VOA, "Pelanggaran Kebebasan Beragama Terbanyak Terjadi Di Jabar Dan Jakarta," VOA Indonesia.

${ }^{4}$ Theofilus MEDCOM, "180 Pelanggaran Kebebasan Beragama Terjadi Selama 2020," Medcom.Id.

${ }^{5}$ Anwar Hidayat, "Penelitian Kualitatif (Metode): Penjelasan Lengkap - Uji Statistik," Statiskian.
} 
sia yang tertib dan teratur. Dari pengertian tersebut sudah seharusnya agama bisa membawa persatuan dan kesatuan bangsa. Namun pada kenyataannya masih banyak orang yang tidak mengerti konsep agama. Indonesia adalah negara hukum yang menjunjung tinggi hak-hak kemanusiaan, dan kebebasan memeluk agama/keyakinan merupakan bagian dari hak setiap individu, terlebih lagi dalam Pancasila pasal 1 "Ketuhanan Yang Maha Esa" Indonesia percaya bahwa pengakuan hati nurani rakyat yang berdasar hanya kepada rahmat Tuhan Yang Maha Esa.

Agama merupakan murni keputusan pribadi dimana negara wajib melindungi hak tersebut serta HAM juga merupakan hak konstitusional yang statusnya paling tinggi dalam hierarki norma-norma hukum yang berlaku. Negara wajib menjamin warganya dalam memeluk suatu keyakinan atau agama dan juga pemerintah harus melindungi warganya dalam hal menjalankan peribadatannya masing-masing, selama tidak menyalahgunakan aturan perundang-undangan, tidak menodai agama, serta tidak mengganggu ketentraman masyarakat.

Dalam beberapa kasus, contohnya adalah yang terjadi ditahun 2020 lalu dimana pembangunan gereja di wilayah Tanjung Balai Karimun, Kepulauan Riau ditolak oleh warga sekitar padahal sudah memiliki izin membangun dari pemerintah penolakan disebabkan karena warga merasa wilayahnya adalah mayoritas muslim. ${ }^{6}$ Kemudian kasus penolakan pemakaman jenazah bayi yang berusia dua bulan dan beragama Kristen di Desa Menganti, Gresik, Jawa Timur warga menolak pemakaman dilakukan karena lagi-lagi dengan alasan wilayahnya mayoritas muslim. ${ }^{7}$ Dan masih banyak kasus lainnya terkait pelanggaran HAM dalam keberagamaan.

Faktor pemicu terjadinya sikap intoleransi dalam bermasyarakat, pertama adalah tirani mayoritanisme atau prilaku yang cenderung bersikap egois, arogan, despotik dan superior serta merasa mereka yang paling berhak untuk memimpin. Sikap ini juga didasari oleh komunitas atau kelompok yang mendominasi dan diistimewakan dari pada kelompok minoritas lainnya, mereka merasa yang paling bisa berkuasa dan pada akhirnya melakukan pengucilan kepada kaum minoritas. Tujuan mereka adalah membuat minoritas merasa tidak nyaman dan tersingkirkan.

Faktor kedua ketidaktegasan pemerintah dalam pemenuhan HAM. Peran negara atau pemerintah adalah menjamin dan melindungi kebebasan beragama rakyatnya yang tertuang dalam UUD 1945 pasal 27-34, UU RI no 39 tahun 1999. Negara dapat dikatakan berhasil jika mampu melindungi hak-hak warganya dengan baik. Alasan utama dalam kehadiran suatu negara adalah melindungi warganya. Negara juga wajib menjaga eksistensi keberadaan agama dalam kehidupan bermasyarakat, Indonesia mengakui adanya beberapa agama (Islam, Kristen, Khatolik, Hindu, Budha dan Konghuchu). Negara masih memberikan kesan pembatasan kebebasan beragama dalam aspek forum externun atau sikap hati nurani didepan umum yang tidak sesuai, padahal kebebasan beragama adalah aspek forum infernum atau kebebasan asasi yang dimiliki pribadi. ${ }^{8}$

Beragam keunikan dan keyakinan jika negara tidak mampu membingkainya dengan baik dan benar maka cenderung akan menimbulkan pertentangan dan menciptakan konflik-konflik

\footnotetext{
${ }^{6}$ Ayomi Amindoni, “Pembangunan Gereja Di Tanjung Balai Karimun Ditolak Warga Meski Sudah Kantongi IMB, Mengapa Aksi Intoleransi Terus Terjadi? - BBC News Indonesia," BBC News.

${ }^{7}$ Ronald Seger Prabowo, "Miris! KK Beragama Kristen, Pemakaman Jenazah Bayi Ditolak Warga - Suara Jateng," SuaraJawaTengah.ID.

${ }^{8} \mathrm{JIn}$ Sd et al., "( RELIGIOUS FREEDOM IN THE FRAME OF STATE AUTHORITY ) Fathuddin , S . HI , SH , MA . Hum Aktivis Lakpesdam NU Dan Mahasiswa Magister Ilmu Hukum Program Pascasarjana Fakultas Hukum Universitas Indonesia A . Pendahuluan Kementerian Agama Saat Ini Sedang Men" (2015): 1-25.
} 
sosial. Sehingga sangat penting menghargai sistem hukum dan nilai-nilai suatu bangsa karena dari sana akan tercermin keberadaan suatu negara yang melindungi warganya. Pemerintah tidak boleh berat sebelah terhadap suatu keyakinan saja, oleh sebab itu peraturan yang dibuat harus bersifat seadil-adilnya bagi rakyat, termasuk peraturan yang menyangkut agama.

Mengapa pentingnya melakukan perlindungan terhadap agama, menurut Prof. Oemar Senoadji, SH mengemukakan landasan dan urgensi mengapa negara perlu mengatur agama, pertama Religionsschutz-Theorie (teori perlindungan "agama"), agama merupakan bagian dari kepentingan hukum dan objek yang wajib dilindungi melalui undang-undang. Kedua. Gefüh/sschutz-Theorie (teori perlindungan "perasaan keagamaan"), kepentingan hukum yang akan dilindungi adalah "rasa/perasaan keagamaan" dari orang-orang yang beragama. Ketiga, Friedensschutz-Theorie (teori perlindungan "perdamaian/ ketentraman umat beragama"). Objek atau kepentingan hukum yang dilindungi menurut teori ini adalah "kedamaian/ketentraman beragama interkonfessional di antara pemeluk agama/kepercayaan." ${ }^{\prime 9}$

Dalam menghadapi permasalahan HAM khususnya keberagamaan harus dilakukan secara bersama-bersama antara masyarakat dan pemerintah, dengan persatuan dan semangat gotong royong pelanggaran HAM dan keberagamaan dapat dihindari atau setidaknya berkurang. Sikap intoleransi kebanyakan timbul dari rasa takut dan ketidakpahaman seseorang terhadap perbedaan budaya, bangsa dan agama, ketidakpahaman tersebut membuat seakan diri dan kepercayaannya adalah sesuatu yang paling benar atau baik. Padahal setiap manusia lahir, tumbuh dan berkembang dalam lingkungan yang berbeda-beda sehingga pola pikir seseorang pasti akan berbeda, disinilah peran negara atau pemerintah harus bertindak tegas dalam menghadapi perilaku intoleransi.

Hal yang harus dilakukan demi terciptanya kerukunan kehidupan umat beragama. Pertama pemerintah harus bersikap tegas dalam menindaklanjuti pelanggaran HAM dan mulai melakukan sosialisasi secara berkala mengenai pentingnya menghargai perbedaan atau bersikap toleransi yang merupakan bagian dari HAM. Sosialisasi dapat dimulai dari lingkungan pendidikan atau sekolah, aparatur negara, pemerintah daerah dan kepada masyarakat langsung. Tugas pemerintah didalamnya termasuk aparatur negara wajib menjaga kebebasan beragama dalam kehidupan bermasyarakat, berbangsa dan bernegara.

Kedua, pemerintah harus mengevaluasi peraturan perundang-undangan yang memiliki indikasi-indikasi tidak menerapkan HAM didalamnya. Peraturan yang dibuat memiliki unsur keberpihakan pada satu keyakinan atau satu kelompok saja dan tidak mencakup kepentingan hajat hidup orang banyak. Serta memberikan pelatihan dan pemahaman bagaimana membuat peraturan perundang-undangan yang baik untuk masyarakat menyeluruh. ${ }^{10}$ Ketiga, mengadakan dialog antar agama yang bertujuan bukan untuk berdebat tentang pengajaran agama tetapi agar terciptanya perjumpaan teologis, sosiologis sekaligus psikologis antar-umat beragama. Karena sikap saling mencurigai dan kebencian mengawali sikap intoleransi. Serta menekankan persoalan bahwa setiap individu memiliki keberagaman (ras, suku dan agama) yang berbeda dan unik tetapi sebenarnya memiliki nilai moral dan etika yang sama, yaitu kebaikan.

\section{Peran Gereja Dalam Penegakan HAM}

Alkitab menuliskan dalam Kejadian Berfirmanlah Allah: "Baiklah Kita menjadikan manusia menurut gambar dan rupa Kita, supaya mereka berkuasa atas ikan-ikan di laut dan bu-

\footnotetext{
${ }^{9}$ Dian Andriasari, "Teori Pidana - CRCS UGM," Crcs.Ugm.Ac.Id.

${ }^{10}$ Victorio H Situmorang, "Kebebasan Beragama Sebagai Bagian Dari Hak Asasi Manusia," Jurnal HAM 10, no. 1 (2019): 57.
} 
rung-burung di udara dan atas ternak dan atas seluruh bumi dan atas segala binatang melata yang merayap di bumi." Sebabnya Allah menciptakan manusia itu menurut gambar-Nya, menurut gambar Allah diciptakan-Nya dia; laki-laki dan perempuan diciptakan-Nya mereka. Jelas sekali dalam ayat tersebut manusia mempunyai kedudukan tertinggi diantara semua mahkluk ciptaan. Jadi Gereja mengakui HAM berasal daripada Tuhan dan gereja mengakui serta melindungi HAM sebagai tugas panggilannya.

Peran gereja dalam penegakan HAM diantaranya memasukan nilai-nilai kemanusiaan yang bermartabat, saling menghormati, keadilan, kejujuran, kedamaian, cintakasih dalam setiap tindakan dan perilaku, gereja harus bisa menjadi contoh teladan dalam menghargai dan melindungi HAM. Gereja juga harus mampu bersikap adil, tegas dan benar terhadap persoalan-persoalan yang terjadi untuk menghormati dan mengembangkan HAM dimanapun berada dan terhadap siapapun, tidak hanya kepada anggota gereja tetapi kepada semua manusia tanpa terkecuali, karena Tuhan menciptakan manusia dengan cara yang sama tanpa membedabedakan satu dan lainnya.

\section{KESIMPULAN}

Konsep agama adalah sebuah keyakinan yang menghindarkan manusia dari kekacauan dengan kata lain agama bisa mempersatukan manusia karena pada dasarnya nilai-nilai yang terkandung didalamnya adalah sama yaitu sebuah kebaikan yang mutlak dan tidak pandang bulu. Indonesia sebagai negara hukum meletakan nilai HAM sebagai yang tertinggi diantara hirarki norma hukum umum lainnya. Dengan demikian negara wajib menjamin dan melindungi warganya untuk memeluk keyakinannya serta menjalankan ibadahnya, sesuai yang tertera dalam UUD NRI 1945 pasal 29 (2), kemudian dijabarkan lebih detail dalam UU RI Nomor 39 Tahun 1999 tentang Hak Asasi Manusia.

Hak konstitusi itu lah harus dihormati dan dihargai oleh sesama manusia, banyak kasus terjadi dalam hal pelanggaran HAM dan semakin kita mengabaikan maka negara akan hancur. Faktor pemicu terjadinya pelanggaran HAM adalah tirani mayoritanisme atau prilaku yang cenderung bersikap egois, arogan, despotik dan superior serta ketidaktegasan pemerintah dalam pemenuhan HAM karena masih mengedepan kan aspek sikap hati didepan umum (forum externum) padahal keberagamaan adalah HAM yang sangat pribadi (forum internum) yang tidak boleh dipaksakan dan diganggu.

Penanganan dalam pelanggaran kebebasan beragama harus dilakukan segera oleh negara atau pemerintah bersama-sama dengan masyarakat, maka dari itu harus yang harus dilakukan adalah pemerintah harus bertindak adil dan tegas dalam menindaklanjuti pelanggaran HAM khususnya kebebasan beragama serta mulai melakukan sosialisasi pentingnya menjaga toleransi antar umat beragama karena bagian dari HAM. Kemudian mengevaluasi undang-undang yang terkait kebebasan beragama yang memiliki unsur keberpihakan hanya untuk satu golongan saja. Dan melakukan dialog antar umat agar terciptanya perjumpaan teologis, sosiologis sekaligus psikologis antar-umat beragama.

Gereja juga harus mendukung penuh berjalannya HAM dalam kehidupan dapat tercipta dengan baik, karena gereja mengakui HAM merupakan anugerah dari Tuhan. Melalui programprogram, kothbah atau setiap aktivitas harus menerapkan nilai-nilai kemanusiaan dan mampu bersikap tegas dan adil dalam setiap persoalan yang terjadi didalamnya. 


\section{REFERENSI}

Alkitab Bahasa Indonesia Terjemahan Baru (2008). Lembaga Alkitab Indonesia Jakarta Andriasari, Dian. "Teori Pidana - CRCS UGM." Crcs.Ugm.Ac.Id.

Ayomi Amindoni. "Pembangunan Gereja Di Tanjung Balai Karimun Ditolak Warga Meski Sudah Kantongi IMB, Mengapa Aksi Intoleransi Terus Terjadi? - BBC News Indonesia." BBC News.

Dewan Perwakilan Rakyat. "Undang Undang Dasar 1945." DPR.Go.Id.

Fathiyah Wardah VOA. "Pelanggaran Kebebasan Beragama Terbanyak Terjadi Di Jabar Dan Jakarta." VOA Indonesia.

Hidayat, Anwar. "Penelitian Kualitatif (Metode): Penjelasan Lengkap - Uji Statistik." Statiskian.

Indonesia, Republik. "Undang-Undang No . 39 Tahun 1999 Tentang : Hak Asasi Manusia." Pusat Penerbitan, PNRI, no. 39 (1999): 43.

Prabowo, Ronald Seger. "Miris! KK Beragama Kristen, Pemakaman Jenazah Bayi Ditolak Warga - Suara Jateng." SuaraJawaTengah.ID.

Sd, Jln, Inpres No, Rt Pisangan, and Barat Kelurahan. "( RELIGIOUS FREEDOM IN THE FRAME OF STATE AUTHORITY ) Fathuddin, S . HI , SH , MA . Hum Aktivis Lakpesdam NU Dan Mahasiswa Magister Ilmu Hukum Program Pascasarjana Fakultas Hukum Universitas Indonesia A . Pendahuluan Kementerian Agama Saat Ini Sedang Men" (2015): 1-25.

Situmorang, Victorio H. "Kebebasan Beragama Sebagai Bagian Dari Hak Asasi Manusia." Jurnal HAM 10, no. 1 (2019): 57.

Theofilus MEDCOM. "180 Pelanggaran Kebebasan Beragama Terjadi Selama 2020." Medcom.Id. 